\title{
2015 California Climate Action Planning Conference Keynote Address
}

\author{
Salud Carbajal \\ Santa Barbara County Supervisor
}

\begin{abstract}
In August 2015, Cal Poly's CRP Department hosted the second Climate Action Planning Conference to discuss local, state, national and international climate issues. The keynote address was provided by then Santa Barbara County Supervisor Salud Carbajal. His words framed the action-oriented vision for the conference, and define much of what the CRP family continues to focus on as a part of their teaching and scholarship.
\end{abstract}

$T$ ank you for inviting me to say a few words today about my experiences. I want to start by thanking everybody who's had a role in putting together this planning conference. Let me start by saying that elected officials are jacks-of-all-trades. So it kind of concerns me a little bit when I was invited to say to say a few works to you today because all of you are planners and experts in various subjects, including climate change.

So I was a little bit intimidated planning my remarks to come here today to address you. But various experiences have afforded me interesting observations and perspectives. These include: having served as a county staff to a previously elected county supervisor, an elected official going on eleven years, as a member of the President's Local, State and Tribal Leaders Task Force on Climate Preparedness and Resiliency, and having worked with the US EPA.

We are lucky to live in a State and region where both Republican and Democrat governors have signed landmark legislation to address the problem of climate change. You have no idea how this makes us standout throughout the country. Having served on a number of national committees and organizations in various capacities, I understand that California is like a different nation.

Gubernatorial leadership has resulted in significant action to reduce greenhouse gas emissions in California. This has made California an unequivocal leader in our nation and a beacon of hope on this important issue. You know what they say, "As California goes, so does the nation, or so goes the nation." Assembly Bill (AB) 32 signed by Governor Schwarzenegger in 2006, is considered the first comprehensive public policy effort in the United States to address climate change and greenhouse gas emissions. It set us on a course to reduce emissions to 1990 levels by 2020 .

$A B 32$ required the air emissions board to develop a scoping plan to meet emissions reductions from virtually all sectors of the economy, including energy production, fuels, cars and trucks. Senate Bill (SB) 375, adopted in 2008, coordinates housing and transportation planning efforts, , to reduce greenhouse gas emissions from motor vehicles by integrating land use and transportation planning policies at the local level. Moreover Governor Brown's recent executive order to establish reductions in greenhouse gas emissions to $40 \%$ of 1990 levels by 2030 , and $80 \%$ below 1990 levels by 2050 has once again set the example.

This state framework has created the incentive, momentum and mandate to encourage local governments to follow suit and develop our local innovative energy savings programs -greenhouse gas emissions reductions targets, strategies and local climate action plans. More importantly, these efforts have culminated in growing the mass dialogue and movement in communities throughout the state. Governor Brown has also provided a policy directive to all state government departments and agencies, requiring them to address climate change within their scope of responsibility and operations.

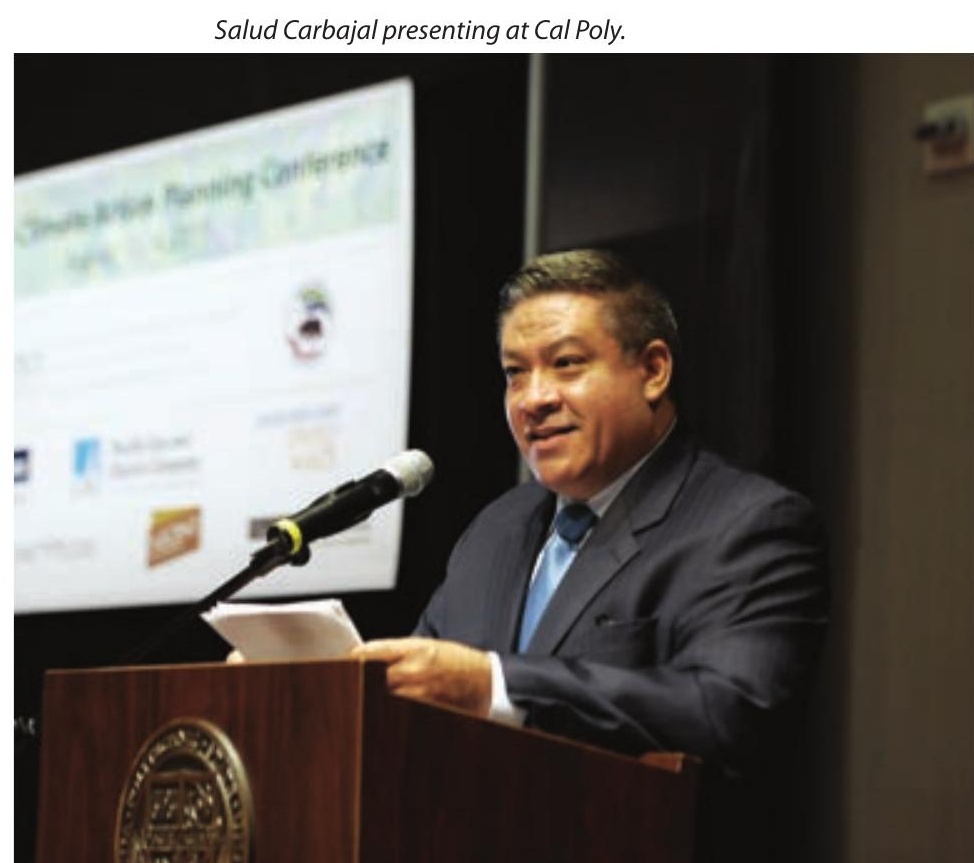


While some states and local governments are taking significant steps to address this important issue, the federal government traditionally has lagged on making strides in policy and progress on this subject with the exception of the US EPA. I am happy that this attitude and historic federal posture came to a dramatic change with the Obama Administration, which has made addressing climate change a cornerstone of their policy agenda. In June 2013, President Obama released his climate action plan, which sought to develop strategies, goals and directives to cut carbon pollution, to prepare the US for the impacts of climate change on our infrastructure, economy and natural resources, and to engage the international community to take action.

Furthermore, President Obama issued an Executive Order in November 2013 that took a multifaceted approach to modernize federal programs to support resilient investments, manage lands and water for preparedness and resilience, provide information, data and tools to plan for resilience, and plan and assess future risks from climate change. To implement this action the executive order established an interagency council on climate preparedness comprised of 25 federal agencies. The executive order also established the State, Local and Tribal Leaders Climate Task Force, which met for one year and was comprised of 26 members, consisting of 8 governors, 13 mayors, 3 supervisors and 2 tribal members. It was a bipartisan task force. The charge of the Task Force was to provide recommendations on how the federal government can better respond to the needs of communities nationwide dealing with the impacts of climate change.

On November 2014, the Task Force Final Report was submitted to the President and included over 500 recommendations, which were distilled into 50 priority actions. The recommendations were developed from the following overarching guiding principles: (1) Federal regulations and funding programs must include more consideration of climate risk and vulnerabilities; (2) Maximize projects that both mitigate greenhouse gas emissions and build resilience; (3) Enhance interagency coordination and cooperation; (4) Consult and cooperate with tribes in indigenous communities; (5) Break down silos and improve coordination among federal agencies. The Task Force's progress to date includes development of enhanced data and tools as sought initially, sharing of best practices and ongoing funding, and funding of new programs and initiatives.

When considering the challenges and scope of climate change, President Obama said it best: "2014 was the planet's warmest year on record. Fourteen of the fifteen hottest years on record have all fallen in the first fifteen years of this century. The past winter in aggregate was the warmest winter ever recorded. This is not a problem for another generation; not anymore. This is a problem now. It has serious implications for the way we live right now - stronger storms, deeper droughts, longer wildfire seasons. The world's top climate scientists are warning that a changing climate already affects the air that our children are breathing."

He goes on to say, "the Surgeon General and I recently met with doctors, nurses and parents who see patients and kids grappling with health impacts. The Pentagon says that climate change poses an increasing set of risk to our national security, so climate change can no longer be denied. It can't be edited out. It can't be omitted from the conversion, and action can no longer be delayed." President Obama, April 15, 2015.

Here on the Central Coast, at the local level, we also have been able to make significant progress on addressing the issue of climate change. Starting with expanding the conversation through local forums and symposiums such as this one today. Your participation continues efforts to work together to explore what we can do better in terms of planning and adopting resilience strategies in the future.

In 2013, while working with the Community Environmental Council (CEC) and the International Coalition of Local Environmental Initiatives (ICLEI), we organized a tri-county climate change symposium consisting of elected officials, appointed public interest groups and non-profit, environmental and business stakeholders. This led to growing interest in developing networks amongst public, non-governmental and private sector, reaffirmed the need to share data across jurisdictional boundaries, and reached a consensus to engage in a regional municipal collaborative effort.

Subsequently, supervisors from Ventura County, San Luis Obispo, and I met with our respective staffs to discuss expansion of the Santa Barbara County Empower Program, and the possibility of developing a regional Community Choice Energy program like those that exist in Lancaster, Sonoma, and Marin.

I report to you today that we have a tri-county Empower Program, and Santa Barbara County has initiated a feasibility study for a regional Community Choice Energy project with support from the Community Environmental Council, County of Ventura and the City of Santa Barbara. In addition, other tricounty municipalities have been invited, including the Cities and County of San Luis Obispo. For those of you that live in San Luis Obispo, now is a time to approach decision makers to encourage them to collaborate with us, and at the very least to support this feasibility study, which will be very instructive and informative as to the opportunities that CCA or CCE will provide to our region.

Moreover, Santa Barbara County has adopted an Energy and Climate Action Plan on a bipartisan vote and set high greenhouse gas emissions standards that hold one thousand metrics tons per year for new industrial projects to mitigate their emissions, which would capture $99 \%$ of their greenhouse gas emissions. 
I have found that there are good people from all perspectives who are working together take initiative and action to both adapt and mitigate. But, in my opinion, there is one specific area where many of our efforts oftentimes fall short. This is engaging the private sector. To our detriment the lack of collaboration with the private sector in a substantive way, has enabled the false narrative that environmental sustainability and economic prosperity are opposing ideals. Nothing could be further form the truth. Creating sustainable communities is both good for business and our environment, and of course the economy overall. To really get to where we need to be in terms of enacting more resilient and adaptive climate policy the private sector must be included in a more substantive way.

As climate policy is constantly evolving, I have also observed that the discussion and focus has shifted more from mitigation to adaptation. I believe that we must do both, which means to continue to incorporate mitigation strategies as we adopt stringent adaptation policies. To do both is a daunting challenge but the predicted outcome of a business-as-usual alternative, which means continuing the use of extensive fossil fuels and increasing greenhouse gas emissions, should serve as our motivation to reaffirm the purpose and importance of our collective work.

Business-as-usual means more oil spills like the recent Refugio spill on the treasured Gaviota Coast in Santa Barbara. It means debating whether to approve the Phillips 66 rail spur project that would support oil trains carrying tar sands oil from Canada to the Central Coast. Approval would mean significant risk to the health and public safety of our residents, threats to our economy, and major jeopardy to the natural environment and coastline of the Central Coast. It means more fracking that threatens to contaminate our water basins, intensified use of water supply, and increased greenhouse gas emissions. It means recognizing extended droughts, year round fire seasons, floods, and rising sea levels. I could go on and on and on - they continue.

When I compare these few examples of the business-as-usual paradigm with an alternative of a sustainable and a resilient future, the choice is clear. In closing I want to reiterate how fortunate we are to live in a region and in a state that are international leaders on climate policy. I appreciate the opportunity you have given me to share with you just a few thoughts about some the efforts I've been involved with. I want to conclude by quoting Pope Francis, "We are not faced with two separate crises one environmental and the other social, but rather one complex crisis which is both social and environmental." Thank you very much. 